\title{
Influence of Growth Hormones on Initiation of Somatic Embryogenesis in Coconut var. Chowghat Orange Dwarf
}

\author{
R. Renuka*, J. Ann Greeshma, N. Nirmala and R. Meera \\ Plant Tissue Culture Laboratory, Department of Plant Biotechnology, Centre for Plant \\ Molecular Biology and Biotechnology, Tamil Nadu Agricultural University, \\ Coimbatore - 641 003, India \\ *Corresponding author
}

\section{A B S T R A C T}

\begin{tabular}{|c|}
\hline Keywords \\
\hline $\begin{array}{l}\text { Coconut, } \\
\text { Embryogenic calli, } \\
\text { Translucent } \\
\text { structures, } \\
\text { Embryogenic } \\
\text { structures, 2,4-D } \\
\text { and kinetin }\end{array}$ \\
\hline Article Info \\
\hline $\begin{array}{l}\text { Accepted: } \\
22 \text { October } 2018 \\
\text { Available Online: } \\
10 \text { November } 2018\end{array}$ \\
\hline
\end{tabular}

\section{Introduction}

Coconut (Cocos nucifera L.), is an important perennial crop cultivated across the globe in tropics and humid tropics. In India, the coconut palms occupies an area of 2.08 million ha with the production of 23904 million nuts year ${ }^{-1}$ and productivity of 11481 nuts ha ${ }^{-1}$ (www.coconutboard.nic.in/Statistics. aspx). Although India has attained the foremost position globally in production, the productivity of the palm has to be improved.

\begin{abstract}
Coconut (Cocos nucifera L.), is an important perennial crop cultivated across the globe. The demand for quality planting materials is increasing across the world for the establishment of new orchards, rejuvenation of existing orchards and production of quality nuts. Plant tissue culture is an alternate approach for the production of quality planting material. In this investigation, influence of auxin and cytokinin on somatic embryogenesis in coconut is studied using sliced mature embryos as explants in modified Y3 media supplemented with various concentrations of 2,4-D and kinetin. Maximum embryogenic calli and translucent structures were formed in Y3 modified media supplemented with equal concentration of 2,4-D and kinetin $(100 \mu \mathrm{M}, 200 \mu \mathrm{M}$ and $300 \mu \mathrm{M})$. Maximum embryogenic structures were formed in Y3 media supplemented with high concentration of 2,4-D $(450 \mu \mathrm{M})$ and with lower concentration of Kinetin $(100 \mu \mathrm{M})$. Further, these embryogenic structures on culturing in media supplemented with cytokinin will form globular embryos.
\end{abstract}

Limitations in improving productivity of coconut palm are due to its perennial and heterozygous nature. Quality planting materials are the fundamental input for the establishment of new orchards, rejuvenation of existing orchards by replacing diseased, senile and aged palms and the production of quality nuts. Hence, the demand of quality seedlings and nuts are rapidly increasing for establishing plantations.

Natural vegetative propagation is not possible 
in crops like coconut where, production of true to type elite planting material becomes a herculean task. Further to add on to the complication, coconut is one of the most recalcitrant species to regenerate under in vitro conditions. Earlier, in vitro studies in coconut were carried out using a range of explants for the production of plantlets viz., immature inflorescence (Branton and Blake, 1983; Verdeil et al., 1994), tender leaf (Raju et al., 1984; Buffard-Morel et al., 1995), mature embryos (Karun et al., 1999), immature zygotic embryo (Karunaratne and Periyapperuma, 1989; Fernando and Gamage, 2000), plumules (Chan et al., 1998; Fernando et al., 2003; Karun et al., 2004) and unfertilized ovaries (Perera et al., 2007). Hornung and Verdeil (1999) showed that the callusing frequency in explants of leaf and immature inflorescence were very low (20 and 30 per cent respectively) and reported that the results were not consistent. The studies of Chan et al., (1998) and Fernando et al., (2010) revealed that the response of pumule explants under in vitro culture through somatic embryogenesis was better in terms of callus formation and embryogenic capacity. Similarly, Hornung and Verdeil (1999) concluded that somatic embryogenesis is viable approach for coconut micropropagation. Perez-Nunez et al., (2006) proved the possibility of producing 35,00050,000-fold increased somatic embryo formation through secondary somatic embryogenesis and embryogenic calli multiplication using plumule explants.

Somatic embryogenesis in coconut is highly influenced by media components. Samosir et al., (1999) and Fernando and Gamage (2000) reported that manipulation of auxin and ABA levles in the culture medium improved the somatic embryogenesis and plant regeneration. The presence of $\mathrm{ABA}$ in combination with high agar concentration induced water stress leading to improvement in plant regeneration (Fernando et al., 2010). However, the low reproducibility, low efficiency of somatic embryogenesis and poor plant regeneration in coconut compels to explore other strategies to improve somatic embryogenesis in coconut. In this context, the study was proposed to investigate the influence of plant growth hormones viz., 2,4-D and kinetin in culture medium on the formation of callus, translucent structures and embryogenic structures.

\section{Materials and Methods}

Twelve months old nuts were harvested from Chowghat Orange Dwarf (COD) palms free from pest and diseases with high yield. The cultivar was maintained at Coconut Research Station, Aliyar Nagar, Tamil Nadu Agricultural University, situated at $10^{\circ} \mathrm{N}$ latitude and $77^{\circ} \mathrm{E}$ longitude, at an altitude of $260 \mathrm{~m}$ above mean sea level. One of the preferred cultivar for tender coconut in Tamil Nadu is COD.

\section{Embryo isolation}

Coconut mature embryos were isolated from 12 months old nuts. The fibrous mesocarp was removed and nuts were cut transversely with a machete. One portion of the broken nut containing eyes was used for embryo isolation. The endosperm cylinder containing the embryo was removed using a tender coconut opener. Endosperm cylinders were stored in 1 per cent sodium hypochlorite for transport to the laboratory.

\section{Sterilization of endosperm cylinders and embryos}

Under aseptic conditions, the endosperm cylinders enclosing the embryos were washed in sterile distilled water and were transferred to $70 \%$ ethanol for $3 \mathrm{~min}$ and rinsed with sterile distilled water, followed by $4 \%$ sodium 
hypochlorite solution wash for $20 \mathrm{~min}$ and rinsed with sterile distilled water. The embryos excised from the endosperm cylinders were subjected to $0.6 \%$ sodium hypochlorite solution for $10 \mathrm{~min}$ and rinsed with sterile distilled water thrice.

\section{Culture medium and conditions}

The sterilised embryos were cultured in the modified Y3 medium supplemented with sucrose $(4.5 \%)$, activated charcoal $(0.25 \%)$, agar $(0.8 \%)$ combined with growth hormones viz., 2,4-D and kinetin (kin) each at various concentration $(150 \mu \mathrm{M}, 300 \mu \mathrm{M}, 450 \mu \mathrm{M}$ and $600 \mu \mathrm{M})$. Modified Y3 basal medium $\left(\mathrm{T}_{1}\right)$ served as control for the experiments (Table 1). The media was autoclaved at $15 \mathrm{psi}$ $\left(1 \mathrm{~kg} / \mathrm{cm}^{2}\right)$ at $121^{\circ} \mathrm{C}$ for 20 minutes. At bearable warmth the media was dispensed into Petriplates and stored until further use. The sterilized embryos were sliced into small pieces and inoculated into the medium. The cultures were incubated at $25 \pm 2{ }^{\circ} \mathrm{C}$ and relative humidity of $60 \%$ under dark conditions for 60 days followed by $16 / 8 \mathrm{~h}$ photoperiod regime $\left(36 \mu \mathrm{mol} \mathrm{m} \mathrm{m}^{-2} \mathrm{~s}^{-1}\right)$. The experiments were replicated sufficiently.

\section{Data analysis}

Statistical analysis was performed by adopting Completely Randomized Design (CRD) as per standard procedure of Panse and Sukhatme (1985) and Duncan's Multiple Range Test (DMRT). Analysis was carried out with MS Excel spread sheet and DSAASTAT software.

\section{Results and Discussion}

Effect of kinetin and 2,4-D on callus initiation

Initial callusing was observed after 3-4 weeks of inoculation. Highest initial callusing was recorded in $\mathrm{T}_{7}(\mathrm{Y} 3+300 \mu \mathrm{M} 2,4-\mathrm{D}+300 \mu \mathrm{M}$ kin) $(55.55 \%)$ followed by $\mathrm{T}_{2}(\mathrm{Y} 3+100 \mu \mathrm{M}$ 2,4-D+100 $\mu \mathrm{M}$ kin) (44.44\%). Treatments $\mathrm{T}_{4}$ $(\mathrm{Y} 3+200 \quad \mu \mathrm{M} \quad 2,4-\mathrm{D}+200 \quad \mu \mathrm{M} \quad$ kin $), \quad \mathrm{T}_{5}$ (Y3+300 $\mu \mathrm{M}$ 2,4-D+100 $\mu \mathrm{M}$ kin) and $\mathrm{T}_{8}$ (Y3 $+450 \mu \mathrm{M} \quad 2,4-\mathrm{D}+100 \quad \mu \mathrm{M} \quad$ kin), were statistically on par and recorded a callusing percentage of $33.33 \%$. Treatment $\mathrm{T}_{3}(\mathrm{Y} 3+200$ $\mu \mathrm{M}$ 2,4-D+100 $\mu \mathrm{M}$ kin) recorded $22.22 \%$ callusing, while $\mathrm{T}_{6}(\mathrm{Y} 3+300 \mu \mathrm{M}$ 2,4-D+200 $\mu \mathrm{M}$ kin) and $\mathrm{T}_{9}(\mathrm{Y} 3+450 \mu \mathrm{M} 2,4-\mathrm{D}+200 \mu \mathrm{M}$ kin) recorded $11.11 \%$ of callusing. In control $\left(\mathrm{T}_{1}\right)$ callus initiation was not observed (Table 2).

\section{Effect of kinetin and 2,4-D on formation of translucent structures}

Translucent structures developed from the calli were observed after 45-50 days of inoculation. Maximum percentage of translucent structures $(44.44 \%)$ were recorded in $\mathrm{T}_{2}(\mathrm{Y} 3+100 \mu \mathrm{M} 2,4-\mathrm{D}+100 \mu \mathrm{M}$ kin $), \mathrm{T}_{4}$ $\left(\mathrm{Y} 3+200 \mu \mathrm{M} 2,4-\mathrm{D}+200 \mu \mathrm{M}\right.$ kin) and $\mathrm{T}_{7}$ $(\mathrm{Y} 3+300 \mu \mathrm{M}$ 2,4-D+300 $\mu \mathrm{M}$ kin) and these treatments were statistically on par. Treatments, $\mathrm{T}_{5}(\mathrm{Y} 3+300 \mu \mathrm{M}$ 2,4-D+100 $\mu \mathrm{M}$ kin) and $\mathrm{T}_{8}(\mathrm{Y} 3+450 \mu \mathrm{M} 2,4-\mathrm{D}+100 \mu \mathrm{M}$ kin), were statistically on par and recorded $33.33 \%$ of translucent structures. Translucent structures of 22.22 and $11.11 \%$ were recorded in $\mathrm{T}_{3}\left(\mathrm{Y} 3+200 \mu \mathrm{M} 2,4-\mathrm{D}+100 \mu \mathrm{M}\right.$ kin) and $\mathrm{T}_{9}$ $(\mathrm{Y} 3+450 \quad \mu \mathrm{M} \quad 2,4-\mathrm{D}+\quad 200 \quad \mu \mathrm{M} \quad$ kin) respectively. In the treatments $T_{1}, T_{10}$ and $T_{11}$, callus was not observed and hence there were no translucent structures (Table 2).

\section{Effect of kinetin and 2,4-D on formation of embryogenic structures}

After 90 days of inoculation, embryogenic structures developed in media supplemented with 2, 4-D and kinetin. Maximum percentage of embryogenic structures (66.66 \%) were recorded in $\mathrm{T} 8(\mathrm{Y} 3+450 \mu \mathrm{M} 2,4-\mathrm{D}+100 \mu \mathrm{M}$ kin) followed by $\mathrm{T} 2(\mathrm{Y} 3+100 \mu \mathrm{M} 2,4-\mathrm{D}+100$ 
$\mu \mathrm{M}$ kin) and $\mathrm{T} 4(\mathrm{Y} 3+200 \mu \mathrm{M} 2,4-\mathrm{D}+200 \mu \mathrm{M}$ kin) $(44.44 \%)$. Treatments $\mathrm{T} 3(\mathrm{Y} 3+200 \mu \mathrm{M}$ 2,4-D+100 $\mu \mathrm{M}$ kin), T5 (Y3+300 $\mu \mathrm{M} 24-$ $\mathrm{D}+100 \mu \mathrm{M}$ kin) and $\mathrm{T} 7(\mathrm{Y} 3+300 \mu \mathrm{M} 2,4-$
$\mathrm{D}+300 \mu \mathrm{M}$ kin) recorded $33.33 \%$ of embryogenic structures and were statistically on par (Table 2 and Fig. 1).

Table.1 Combinations of 2,4-D and kinetin used in this study

\begin{tabular}{|c|l|}
\hline Treatments & Hormonal combinations \\
\hline $\mathbf{T}_{\mathbf{1}}$ & $\mathrm{Y} 3$ Basal \\
\hline $\mathbf{T}_{\mathbf{2}}$ & $\mathrm{Y} 3+100 \mu \mathrm{M} 2,4-\mathrm{D}+100 \mu \mathrm{M}$ kin \\
\hline $\mathbf{T}_{\mathbf{3}}$ & $\mathrm{Y} 3+200 \mu \mathrm{M} 2,4-\mathrm{D}+100 \mu \mathrm{M}$ kin \\
\hline $\mathbf{T}_{\mathbf{4}}$ & $\mathrm{Y} 3+200 \mu \mathrm{M} 2,4-\mathrm{D}+200 \mu \mathrm{M}$ kin \\
\hline $\mathbf{T}_{\mathbf{5}}$ & $\mathrm{Y} 3+300 \mu \mathrm{M} 2,4-\mathrm{D}+100 \mu \mathrm{M}$ kin \\
\hline $\mathbf{T}_{\mathbf{6}}$ & $\mathrm{Y} 3+300 \mu \mathrm{M} 2,4-\mathrm{D}+200 \mu \mathrm{M}$ kin \\
\hline $\mathbf{T}_{\mathbf{7}}$ & $\mathrm{Y} 3+300 \mu \mathrm{M} 2,4-\mathrm{D}+300 \mu \mathrm{M}$ kin \\
\hline $\mathbf{T}_{\mathbf{8}}$ & $\mathrm{Y} 3+450 \mu \mathrm{M} 2,4-\mathrm{D}+100 \mu \mathrm{M}$ kin \\
\hline $\mathbf{T}_{\mathbf{9}}$ & $\mathrm{Y} 3+450 \mu \mathrm{M} 2,4-\mathrm{D}+200 \mu \mathrm{M}$ kin \\
\hline $\mathbf{T}_{\mathbf{1 0}}$ & $\mathrm{Y} 3+450 \mu \mathrm{M} 2,4-\mathrm{D}+300 \mu \mathrm{M}$ kin \\
\hline $\mathbf{T}_{\mathbf{1 1}}$ & $\mathrm{Y} 3+450 \mu \mathrm{M} 2,4-\mathrm{D}+450 \mu \mathrm{M}$ kin \\
\hline
\end{tabular}

Table.2 Effect of 2, 4-D and Kinetin on callus initiation, translucent structure and embryogenic structure formation

\begin{tabular}{|l|c|c|c|}
\hline Treatments & $\begin{array}{c}\text { Callus } \\
\text { Initiation\% }\end{array}$ & $\begin{array}{c}\text { Translucent } \\
\text { structure } \%\end{array}$ & $\begin{array}{c}\text { Embryogenic } \\
\text { structure\% }\end{array}$ \\
\hline $\mathrm{T}_{1}(\mathrm{Y} 3$ basal $)$ & $0.00(0.71)^{\mathrm{f}}$ & $0.00(0.71)^{\mathrm{e}}$ & $0.00(0.71)$ \\
\hline $\mathrm{T}_{2}(\mathrm{Y} 3+100 \mu \mathrm{M} 2,4-\mathrm{D}+100 \mu \mathrm{M}$ kin $)$ & $44.44(6.61)^{\mathrm{b}^{* *}}$ & $44.44(6.61)^{\mathrm{a}^{* *}}$ & $44.44(6.61)^{\mathrm{b}^{* *}}$ \\
\hline $\mathrm{T}_{3}(\mathrm{Y} 3+200 \mu \mathrm{M} 2,4-\mathrm{D}+100 \mu \mathrm{M}$ kin $)$ & $22.22(4.11)^{\mathrm{d}^{*}}$ & $22.22(4.11)^{\mathrm{c}^{*}}$ & $33.33(4.91)^{\mathrm{c}^{*}}$ \\
\hline $\mathrm{T}_{4}(\mathrm{Y} 3+200 \mu \mathrm{M} 2,4-\mathrm{D}+200 \mu \mathrm{M}$ kin $)$ & $33.33(4.91)^{\mathrm{c}^{*}}$ & $44.44(5.70)^{\mathrm{a}^{*}}$ & $44.44(5.70)^{\mathrm{b}^{* *}}$ \\
\hline $\mathrm{T}_{5}(\mathrm{Y} 3+300 \mu \mathrm{M} 2,4-\mathrm{D}+100 \mu \mathrm{M}$ kin $)$ & $33.33(5.81)^{\mathrm{c}^{* *}}$ & $33.33(5.82)^{\mathrm{b}^{* *}}$ & $33.33(5.81)^{\mathrm{c}^{* *}}$ \\
\hline $\mathrm{T}_{6}(\mathrm{Y} 3+300 \mu \mathrm{M} 2,4-\mathrm{D}+200 \mu \mathrm{M}$ kin $)$ & $11.11(2.41)^{\mathrm{e}}$ & $0.00(0.71)^{\mathrm{e}}$ & $0.00(0.71)^{\mathrm{d}}$ \\
\hline $\mathrm{T}_{7}(\mathrm{Y} 3+300 \mu \mathrm{M} 2,4-\mathrm{D}+300 \mu \mathrm{M}$ kin $)$ & $55.55(7.40)^{\mathrm{a}^{* *}}$ & $44.44(5.70)^{\mathrm{a}^{* *}}$ & $33.33(5.81)^{\mathrm{c}^{*}}$ \\
\hline $\mathrm{T}_{8}(\mathrm{Y} 3+450 \mu \mathrm{M} 2,4-\mathrm{D}+100 \mu \mathrm{M}$ kin $)$ & $33.33(5.81)^{\mathrm{c}^{* *}}$ & $33.33(5.81)^{\mathrm{b}^{* *}}$ & $66.66(6.91)^{\mathrm{a}^{* *}}$ \\
\hline $\mathrm{T}_{9}(\mathrm{Y} 3+450 \mu \mathrm{M} 2,4-\mathrm{D}+200 \mu \mathrm{M}$ kin $)$ & $11.11(2.41)^{\mathrm{e}}$ & $11.11(2.41)^{\mathrm{d}}$ & $0.00(0.71)^{\mathrm{d}}$ \\
\hline $\mathrm{T}_{10}(\mathrm{Y} 3+450 \mu \mathrm{M} 2,4-\mathrm{D}+300 \mu \mathrm{M}$ kin $)$ & $0.00(0.71)^{\mathrm{f}}$ & $0.00(0.71)^{\mathrm{e}}$ & $0.00(0.71)^{\mathrm{d}}$ \\
\hline $\mathrm{T}_{11}(\mathrm{Y} 3+450 \mu \mathrm{M} 2,4-\mathrm{D}+450 \mu \mathrm{M}$ kin $)$ & $0.00(0.71)^{\mathrm{f}}$ & $0.00(0.71)^{\mathrm{e}}$ & $0.00(0.71)^{\mathrm{d}}$ \\
\hline $\mathrm{SE}(\mathrm{d})$ & 1.64 & 1.97 & 1.97 \\
\hline $\mathrm{CD}(0.05)$ & 3.40 & 4.09 & 4.09 \\
\hline $\mathrm{CD}(0.01)$ & 4.62 & 5.55 & 5.55 \\
\hline
\end{tabular}

\#data in paranthesis is square root transformed data.

*Significant, ** highly significant 
Fig.1 Initiation of somatic embryogenesis in coconut A) Callus initiation, 45 days after inoculation B) Translucent structures, 60 days after inoculation C) Embryogenic structures, 75 days after inoculation D) Embryogenic structures, 90 days after inoculation
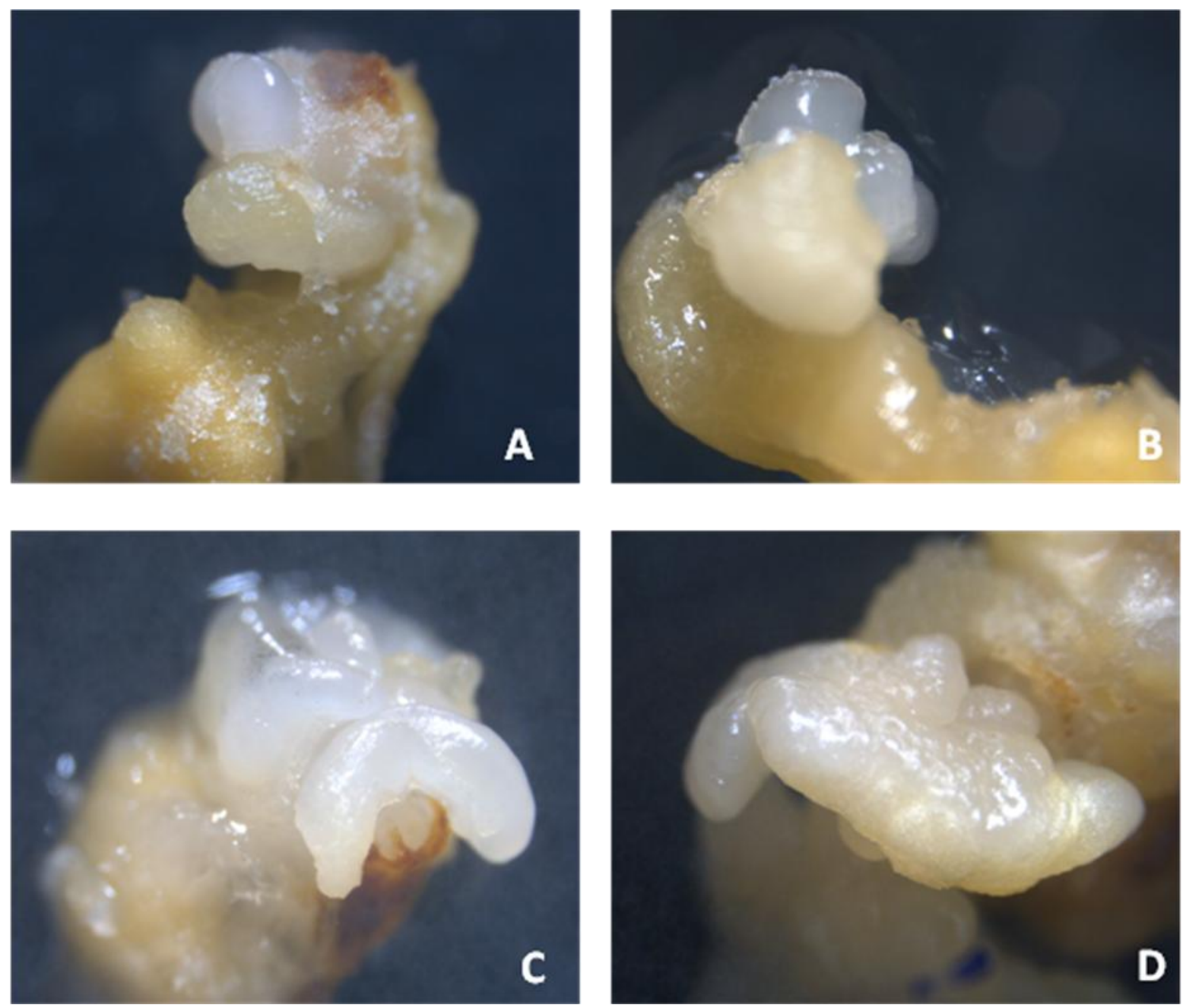

The treatments with Y3+ 2,4- D+ kin were analyzed for callus initiation, translucent structures and embryogenic structure formation. Among these, maximum embryogenic callus initiation was documented in treatment $\mathrm{T} 7(\mathrm{Y} 3+300 \mu \mathrm{M}$ 2,4- D+300 $\mu \mathrm{M}$ kin) (55.55\%). These findings are in agreement with Dudits et al., (1991) and Yeung (1995), where influences of exogenously applied auxins viz., 2, 4-D, on the induction of somatic embryogenesis has been well documented. In more than $65 \%$ of the protocols, 2, 4-D was applied singly or in combination with other plant growth

regulators (Gaj, 2004). The high efficiency of 2,4-D for induction of embryogenic response found in different in vitro systems and plant species indicates a specific and unique character of this plant growth regulator. This synthetic growth regulator and an auxinic herbicide act not only as an exogenous auxin analogue but also as an effective stressor. 2, 4-D brings about different changes in physiology and gene expression of cells and this implicates its possible role as a stress factor triggering embryogenic pattern of development in cultured plant cells (Feher et al., 2003). 
Maximum translucent structures (44.44\%) were recorded in $\mathrm{T} 2(\mathrm{Y} 3+100 \mu \mathrm{M}$ 2,4-D+100 $\mu \mathrm{M}$ kin), T4 (Y3+200 $\mu \mathrm{M}$ 2,4-D+200 $\mu \mathrm{M}$ kin) and $\mathrm{T} 7(\mathrm{Y} 3+300 \mu \mathrm{M} 2,4-\mathrm{D}+300 \mu \mathrm{M}$ kin). While maximum percentage of embryogenic structures $(66.66 \%)$ were recorded in $\mathrm{T} 8(\mathrm{Y} 3+450 \mu \mathrm{M} 2,4-\mathrm{D}+100 \mu \mathrm{M}$ kin) followed by $\mathrm{T} 2(\mathrm{Y} 3+100 \mu \mathrm{M} 2,4-\mathrm{D}+100$ $\mu \mathrm{M}$ kin) and T4 (Y3+200 $\mu \mathrm{M} 2,4-\mathrm{D}+200 \mu \mathrm{M}$ kin) $(44.44 \%)$. In a similar study Ann et al., (2018), reported maximum callusing followed by development of translucent structures and embryogenic structures in Y3 media supplemented with $450 \mu \mathrm{M}$ 2,4-D + and 200 $\mu \mathrm{M}$ BAP. Vidhanaarachchi et al., (2013) reported that on transferring the translucent embryogenic structures of coconut ovary explants to a media with reduced auxin concentration gave nodular structures in the periphery. Further when these structures were subjected to a media free from hormones, these structures enlarged and turned opaque. Sub-culturing of these structures into media containing high cytokinin, they formed globular embryos which showed further development.

This study reveals that maximum embryogenic calli and translucent structures were formed in Y3 modified media supplemented with equal concentration of 2,4-D and kinetin $(100 \mu \mathrm{M}, 200 \mu \mathrm{M}$ and 300 $\mu \mathrm{M})$ while very high concentration of 2,4-D and kinetin although equal $(450 \mu \mathrm{M})$ does not favour embryogenic callus and translucent structure formation. Maximum embryogenic structures were formed in Y3 supplemented with high concentration of 2,4-D $(450 \mu \mathrm{M})$ with lower concentration of kinetin $(100 \mu \mathrm{M})$. It can be concluded that equal concentration of 2,4-D and kinetin plays a significant role in embryogenic callus initiation and translucent structure formation in coconut and for embryogenic structures formation, media comprising higher concentration of 2,4-D and lower concentration of kinetin are required.

\section{Acknowledgments}

The authors acknowledge the financial support provided by Coconut Development Board, Government of India.

Ms. J. Ann Greeshma acknowledges the financial support provided by the Department of Biotechnology, Government of India for pursuing M.Sc. program.

\section{References}

Ann G.J., R. Renuka, R. Meera and Nirmala, N. 2018. Effect of plant growth hormones on development of embryogenic structures in somatic embryogenesis of Coconut. Research Journal of Agricultural Science. (In press)

Branton, R.L., and Blake, J. 1983. Development of organized structures in callus derived from explants of Cocos nucifera L. Annals of Botany. 52(5): 673-678.

Buffard-Morel, J., J.L. Verdeil, S.Dussert, C. Magnaval, C.Huet, and Grosdemange, F. 1995. Initiation of somatic embryogenesis in coconut (Cocos nucifera L.) In: Oropeza C., Howard F.W., Ashburner G.R. (Eds.) Lethal Yellowing: Research and Practical Aspects. Developments in Plant Pathology, vol 5. Springer, Dordrecht. Pp. 217-223.

Chan, J., L.I. Sáenz, C. Talavera, R. Horning, M. Robert and Oropeza C. 1998. Regeneration of coconut Cocos nucifera. $L$. from plumule explants through somatic embryogenesis. Plant Cell Reports. 17(6-7): 515-521.

Dudits, D., L. Bogre and Gyorgyey, J. (1991). Molecular and cellular approaches to the analysis of plant embryo development from somatic cells in vitro. J Cell Sci, 99(3), 473-482. 
Feher, A., T. P. Pasternak and Dudits, D. 2003. Transition of somatic plant cells to an embryogenic state. Plant Cell, Tissue and Organ Culture. 74(3): 201228.

Fernando, S.C., and Gamage, C.K.A. (2000). Abscisic acid induced somatic embryogenesis in immature embryo explants of coconut (Cocos nucifera L.). Plant Science, 151(2), 193-198.

Fernando, S.C., J. L. Verdeil, V.Hocher, L. K. Weerakoon, and Hirimburegama, K. 2003. Histological analysis of plant regeneration from plumule explants of Cocos nucifera. Plant cell, tissue and organ culture, 72 (3): 281-283.

Fernando, S.C., V.R.M. Vidhanaarachchi, L.K. Weerakoon and Santha, E. 2010. What makes clonal propagation of coconut difficult?. Asian Pacific Journal of Moelcular Biology and biotechnology,. 18 (1): 163-165.

Gaj, M. D. 2004. Factors influencing somatic embryogenesis induction and plant regeneration with particular reference to Arabidopsis thaliana (L.) Heynh. Plant Growth Regulation. 43(1): 27-47.

Hornung R and Verdeil J L. 1999. Somatic embryogenesis in coconut from immature inflorescence explants. In: Oropeza C., Verdeil J.L., Ashburner G.R., Cardeña R., Santamaría J.M. (eds) Current Advances in Coconut Biotechnology. Current Plant Science and Biotechnology in Agriculture, vol 35. Springer, Dordrecht. Pp. 297-308.

Karun, A., K.K. Sajini and Shivashankar, S. 1999. Embryo culture of coconut: The CPCRI protocol. Indian J Hortic. 56: 348-353.

Karun, A., K.K. Sajini, E. Radha and Parthasarathy, V.A. 2004. Efficacy of CPCRI protocol of coconut embryo culture in germplasm expedition. Journal of Plantation Crops. 32 (suppl.): 139-143.
Karunaratne, S and Periyapperuma, K. 1989. Culture of immature embryos of coconut, Cocos nucifera L: callus proliferation and somatic embryogenesis. Plant Science. 62(2): 247-253.

Panse, V.G. and Sukhatme, P.V. 1985. Statistical Methods for Agricultural Workers. $4^{\text {th }}$ edition. Indian Council of Agricultural Research Publication, New Delhi. Pp 87-89.

Perera, P. I.P., V. Hocher, J. L. Verdeil, S.Doulbeau, D. M. D. Yakandawala and Weerakoon, L. K. 2007. Unfertilized ovary: a novel explant for coconut (Cocos nucifera L.) somatic embryogenesis. Plant cell reports. 26(1): 21-28.

Perez-Nunez, M.T., J. L. Chan, L. I. Sáenz, T. González, J. L. Verdeil and Oropeza, C. 2006. Improved somatic embryogenesis from Cocos nucifera. $L$. plumule explants. In Vitro Cellular and Developmental Biology-Plant. 42: 3743.

Raju, C.K., P. Prakash Kumar, M. Chandramohan and Iyer, R.D. 1984. Coconut plantlets from leaf tissue cultures. Journal of plantation crops. 12: 75-81

Samosir, Y.M.S., I.D. Godwin and Adkins, S.W. (1999). The use of osmotically active agents and abscisic acid can optimise the maturation of coconut somatic embryos. In: Oropeza C., Verdeil J.L., Ashburner G.R., Cardeña R., Santamaría J.M. (eds) Current Advances in Coconut Biotechnology. Current Plant Science and Biotechnology in Agriculture, vol 35. Springer, Dordrecht. Pp. 341-354.

Verdeil J L, C. Huet, F. Grosdemange and Buffard-Morel, J. 1994. Plant regeneration from cultured immature inflorescences of coconut (Cocos nucifera. L.): evidence for somatic 
embryogenesis. Plant cell reports. 13 (34): 218-221.

Vidhanaarachchi, V.R.M., S.C. Fernando, P.I.P. Perera and Weerakoon, L. K. 2013. Application of un-fertilized ovary culture to identify elite mother palms of Cocos nucifera L. with regenerative potential. Journal of the National
Science Foundation of Sri Lanka, 41(1): 29-34.

Yeung, E. C. 1995. Structural and developmental patterns in somatic embryogenesis. In: Thorpe, T. A. (ed) Embryogenesis in Plants. Kluwer Academic Publishers, Dordrecht. Pp. 205-247.

\section{How to cite this article:}

Renuka, R., J. Ann Greeshma, N. Nirmala and Meera, R. 2018. Influence of Growth Hormones on Initiation of Somatic Embryogenesis in Coconut var. Chowghat Orange Dwarf. Int.J.Curr.Microbiol.App.Sci. 7(11): 2645-2652. doi: https://doi.org/10.20546/ijcmas.2018.711.302 